Article

\title{
Projecting Climate Change Potential of Harvested Wood Products under Different Scenarios of Wood Production and Utilization: Study of Slovakia
}

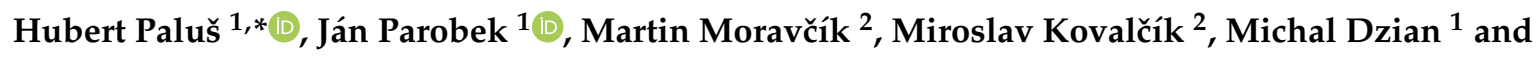 \\ Vlastimil Murgaš ${ }^{2}$ \\ 1 Department of Marketing, Trade and World Forestry, Technical University in Zvolen, T. G. Masaryka 24, \\ 96001 Zvolen, Slovakia; parobek@tuzvo.sk (J.P.); michal.dzian@tuzvo.sk (M.D.) \\ 2 National Forest Centre, T. G. Masaryka 22, 96001 Zvolen, Slovakia; martin.moravcik@nlcsk.org (M.M.); \\ miroslav.kovalcik@nlcsk.org (M.K.); vlastimil.murgas@nlcsk.org (V.M.) \\ * Correspondence: palus@tuzvo.sk; Tel.: +421-455-206-444
}

Received: 24 February 2020; Accepted: 20 March 2020; Published: 23 March 2020

\begin{abstract}
The forestry and forest-based sector play a significant role in climate change mitigation strategies and can contribute to the achievement of a climate-neutral economy. In this context, the ability of harvested wood products (HWP) to sequester carbon is of significant importance. The objective of this work is to make a projection of climate change mitigation potential of HWP, under different scenarios of wood utilization in Slovakia. This study builds on the comparison of different scenarios of industrial wood utilization till 2035 and presents the resulting impacts on the national carbon balance. The results suggest that the development of timber supplies after 2020 in Slovakia will be influenced, in particular, by the future changes in the age distribution and tree species composition as well as the extent of future accidental felling. Consequently, a predicted structure and availability of wood resources in Slovakia will be reflected in a higher share of the production of products with shorter life cycle and thus will negatively affect the carbon pool in HWP. By comparing the results of the four designed scenarios, it follows that the scenario with the greatest mitigation potential, is the one assuming the optimal use of wood assortments and limitation of industrial roundwood foreign trade.
\end{abstract}

Keywords: carbon balance; harvested wood products; wood utilization; roundwood supply; foreign trade

\section{Introduction}

Global climate change is a serious issue influencing the whole planet. Due to the increasing release of greenhouse gases and global warming it has gained great attention in the world [1]. According to the European Commission (EC) [2], the impact of global warming is transforming our environment, increasing the frequency and intensity of extreme weather events. Therefore, immediate and decisive climate action is essential. At national and global levels, long-term climate change mitigation strategies must be adopted to contribute to a achieve prosperous and climate-neutral economy [2-4] and meet the sustainable development goals.

The forestry and forest-based sector can play a significant role in this area. The ability of harvested wood products (HWP) to sequester carbon can be seen as a factor contributing to climate change mitigation [5,6]. A significant share of carbon removed from the forest is moved and stored in HWP [5,7], despite that after forest harvesting immediate losses of carbon to the atmosphere arise as carbon dioxide (decomposition of harvest residues, stump extraction, biomass burning, etc.). Under 
a sustainable forest management regime, carbon stock in forests is stable over time and the forest remains carbon neutral. Carbon sequestered in products adds to the carbon sequestered in forests. Its volume increases with successive harvests and decreases as wood products reach the end of their lifecycle [8]. Nabuurs et al [9] estimated that that EU forests and the forest sector currently produce an overall climate mitigation impact that amounts to about $13 \%$ of the total EU emissions. Pilli at al. [10] concluded that the EU mitigation potential of HWP is about $10 \%$ of the sink forest pools. From this perspective, considering that the lifetime of wood products is variable, priority should be given to long-term applications such as wooden constructions. Carbon sequestering after the product lifecycle can be lengthened by product recycling and reuse. Using residues, recycling (utilization in production) resources or recovered (collected after consumption) resources can be defined as cascading use of wood from trees [11]. The concept of wood cascading can help to optimize the use of wood in the whole chain of its processing and utilization [12]. Sathre and Gustavsson [13] argue that wood cascading can affect the energy and carbon balances through direct substitution of recovered wood (e.g., recycled paper), instead of raw wood, use of wood instead of non-wood alternatives, and prolonging the time of carbon storage in products. The longer the product in a cascade chain the longer carbon stays out of the atmosphere. Gustavsson et al. [14] mentions three different ways of how use of wood products can mitigate greenhouse gasses emission: (i) carbon sequestration by wood; (ii) substituting wood for more energy-intensive materials; and (iii) a direct substitution of fossil fuels by woody biomass to generate energy. In particular, the contribution of HWP to climate change mitigation occurs when they substitute fossil-based resources, as production and application of wood products is related to lower emissions of $\mathrm{CO}_{2}[15,16]$. Changes in the improved utilization of wood assortments may lead to the increased production of HWP with longer life cycle and consequently positively influence the existing HWP carbon pool [6]. Sikkema et al. [17] considered a comparison between the different scenarios of cascaded use of wood and the use of wood for energy and concluded substantially lower greenhouse gases emissions than the Intergovernmental Panel on Climate Change (IPCC) default scenario. Long-term forest management strategies aiming at the increased production of sawlogs could further favor the climate benefits. These benefits follow from the use of sawlog supply for the production of long-lived materials, substitution of fossil-emission and energy intensive materials by wood, and recycling after their useful life to bioenergy [18].

Carbon accounting models are a typical instrument for estimating and forecasting carbon pools. Since 2012, HWP carbon sequestration research has mirrored a new general accounting framework and reporting rules defined for the second Kyoto Protocol commitment period $[5,6]$. This methodology gives valuable techniques and good practice codes for assessing anthropogenic greenhouse gas emissions by sources and removals by sinks stemming from land use or its change and forestry. Accounting shall be based on the change in the harvested wood products pool, estimated using the first-order decay function with default half-lives values. Countries may also use country-specific data to replace the default values and account in accordance with the definitions and estimation methodologies in the most recently adopted IPCC guidelines [19]. Jasinevičius et al. [5] states that national carbon pools of HWP can be dynamic, as a result of the intensive trade and changing trade patterns of HWP among countries. Carbon stock changes in HWP depend on several factors such as harvesting amounts, the final products and their end use, the service life of products, and the disposal/recycling or use as fuel at the end of service life [18].

There are different approaches and methods available to account for carbon stock changes in the HPW pool [5]. Most commonly used are the methodologies of the IPPC production accounting approach $[3,20]$ providing three tiers of methods for estimating annual carbon stock change. These have been applied to many national or regional studies [6,21-26]. Although there are several approaches and methods in place to evaluate the contribution of HWP in terms of climate change mitigation at a national level, the results of analyses may significantly differ depending on the data accessibility, level of their aggregation, and methods used [6,22]. Jasinevičius et al. [27] found out that the volume of carbon stored on HWP can be underestimated when simpler methods and default values (IPCC Tier 2 
method) nonspecific to the country are applied. Findings of Aleinikovas et al. [28] show that carbon inflow into the HWP pool is higher after the application of wood flow analysis contrasted with the IPCC default method. An increase in carbon storage adds extra credits to reporting countries, and can advance the utilization of HWP with longer life cycle to mitigate climate change [27].

There were not many examinations concentrated on carbon balance changes in the HWP carbon pool in Slovakia. Raši et al. [29] estimated the total amount of carbon stored in HWP in Slovakia about $15 \mathrm{Tg}$. Moravčík et al. [30] presented the preliminary results of carbon changes in HWP in relation to the changes in the factors affecting domestic wood flows. Parobek et al. [6] made a comparison of different wood utilization scenarios in Slovakia and estimated the impacts on the carbon balance on a national level. In the suggested scenarios, optimizing of harvested wood assortments and foreign trade variants were considered. The findings indicated that, under the same level of wood harvesting, changing the structure of produced wood assortments can increase the level of carbon stored in HWP.

The objective of this paper is to make a projection of climate change mitigation potential of HWP following from various situations in utilization of wood in Slovakia. The study builds on the comparison of the development of different scenarios of industrial wood utilizations till 2035 and presents the subsequent effects on the national carbon balance. The first scenario (S0 scenario) represents the current situation, which respects the real structure of domestically supplied wood and the current situation in foreign trade. Three additional scenarios (S1, S2, and S3) assume combinations of an improved utilization of available resources and increased domestic consumption of domestically produced timber.

\section{Materials and Methods}

\subsection{Scenarios Determination}

Two main factors related to wood utilization were considered when defining the scenarios. The first factor regarded the differences between the production potential of forests and the utilization of domestically produced wood. The Green Report [31] and expert studies related to production potential of forests in Slovakia [31,32] point out the long-term differences in the quality grades structure of the growing stock and the structure of quality grades of timber assortments supplied to the market. The second factor regarded the volume of industrial roundwood foreign trade. In 2017, over $2 \mathrm{mil.} \mathrm{m}^{3}$ of roundwood was exported, accounting for more than $21 \%$ of the domestic roundwood supply. To eliminate the negative impact of both factors on the level of domestic wood utilization (in terms of the volume and structure) the main strategic documents [33-35] proposed measures to improve the qualitative structure of supplied timber as well as to eliminate the export of roundwood in favor of increased domestic consumption. Based on these assumptions, we defined 4 main scenarios (Table 1).

Table 1. Overview of scenarios.

\begin{tabular}{ccc}
\hline Scenario & Structure of Timber Assortments & Level of Foreign Trade \\
\hline S0 & actual & actual \\
S1 & actual & modelled \\
S2 & modelled & actual \\
S3 & modelled & modelled \\
\hline
\end{tabular}

Note: modelled structure of timber assortments and foreign trade level stand for theoretical assumptions under individual scenarios.

Scenario S0 denotes a basic scenario and reflects the real and forecasted volume and qualitative structure of timber grades produced in forestry in Slovakia including foreign trade. Scenario S1 is referred to as a real scenario excluding foreign trade and reflects the actual and forecasted domestic timber production (its aim is to demonstrate the economic, social, and environmental benefits following from the exclusion of industrial roundwood foreign trade). Scenario S2 (ideal) considers the optimal (available) timber assortment structure and volume that could be supplied by forest owners and 
utilized by the industry (this volume and structure is identical to the actual and projected forest potential). This variant also supposes the optimal use of wood in the wood processing including the recycling of wood residues (sawdust, chips, offcuts, etc.). The last scenario S3 represents the ideal variant excluding foreign trade (theoretical scenario linking the economic, social, and environmental benefits resulting from optimal utilization of available forest potential volume and structure as well as from the increased level of domestic timber consumption).

\subsection{Production and Trade Data}

The following steps were taken to obtain the following types of data:

- quantification of volume and qualitative production of timber divided into groups of coniferous and non-coniferous timber assortments I. - III. quality grade (mainly saw logs) as a basic input for timber production, IV. and V. quality grade (mainly pulpwood) as the basic input for the production of wood pulp and wood-based panels, and VI. grade (predominantly firewood),

- quantification of export and import volumes of timber assortments according to the above-mentioned quality classes. The forecast for foreign trade (export and import volumes) for 2020-2035 was derived from the average volumes over the 5-year period 2013-2017,

- calculation of the domestic consumption of timber assortments quality grades derived as according to the formula: domestic consumption = production + import - export,

- calculation of volumes of semi-finished wood products (sawn wood, wood pulp, and wood-based panels) produced from the available input volumes of timber assortments,

- calculation of the masses of carbon sequestered in the main categories of HWP: coniferous sawnwood, non-coniferous sawnwood, wood-based panels, and paper and paperboard.

Production and wood products trade data, used in the scenario to estimate carbon emissions and removals from HWP in Slovakia, originated from the FAOSTAT database [36]. For all input data (production of industrial wood and fuelwood, export and import of timber assortments, production of HWP) the historical time series for the period from 1989 to 2018 were used; development was forecasted until 2035. The aggregated data reported on each HWP category for Czechoslovakia (1989-1992) were split between Slovakia and Czechia using the data published by Parobek et al. [6].

The actual level of growing stock was derived from the Summary information on forests (SIF) in the Slovak Republic. To determine the quality structure of the production potential of forests, mathematical models based on domestic assortment tables were developed [37-39]. Based on the data of the SIF and National Forest Inventory and Monitoring [40], the total growing stock was divided into the timber quality grades as defined by the Slovak Technical Standards for classification of softwood and hardwood round timber [41,42] as follows: (a) logs of grades I., II. (veneer logs), IIIA. and IIIB. (sawlogs), (b) other industrial roundwood (IV. grade), (c) pulpwood (V. grade), (d) energy and fuelwood (VI. grade), and (e) waste. Other industrial roundwood was incorporated into the pulpwood category. A detailed description of this procedure is explained by Parobek et al. [6].

The forecasted production of wood products was determined on the basis of available resources, i.e., logging and deliveries of roundwood divided into individual quality grades based on the patterns of actual processing in the SR into the following 5 groups (Table 2):

- production of coniferous sawnwood ( $85 \%$ of produced coniferous timber of quality grades I.-III. and $10 \%$ of produced coniferous timber of quality grades IV. and V.);

- production of non-coniferous sawnwood (60\% of produced non-coniferous timber of quality grades I.-III.);

- panel production (5\% of produced coniferous timber of quality grades I.-III. and $65 \%$ of produced coniferous timber of quality grades IV. and V.);

- paper production (30\% of produced non-coniferous timber of quality grades I.-III. and $90 \%$ of produced non-coniferous timber of quality grades IV. and V.); 
- other uses mainly for energy production ( $10 \%$ of produced coniferous and non-coniferous quality grades I.-III., $25 \%$ of produced coniferous timber of quality grades IV. and V. and $10 \%$ of produced non-coniferous quality grades IV. and V.).

Table 2. Distribution of inputs for the production of individual wood products (\%).

\begin{tabular}{lcccc}
\hline \multirow{2}{*}{ Product } & \multicolumn{2}{c}{ I.-III. Quality Grades } & \multicolumn{2}{c}{ IV. and V. Quality Grades } \\
\cline { 2 - 5 } & Timber (C) & Timber (NC) & Timber (C) & Timber (NC) \\
\cline { 2 - 5 } & \multicolumn{5}{c}{$\%$} \\
\hline Sawnwood (C) & 85 & - & 10 & - \\
Sawnwood (NC) & - & 60 & - & - \\
Wood-based panels & 5 & - & 65 & - \\
Paper & - & 30 & - & 90 \\
Other & 10 & 10 & 25 & 10 \\
Total & 100 & 100 & 100 & 100 \\
\hline
\end{tabular}

C-coniferous, NC-non-coniferous.

For the sawnwood production, a conversion factor of 1.54 for coniferous timber and 1.82 for non-coniferous timber was considered. Conversion factors of 1.5 were considered for wood-based panel production and 3.6 for paper production, respectively. A conversion factor determines the volume of timber needed for the production of $1 \mathrm{~m}^{3}$ of a product.

The final sawmills production is divided into sawnwood ( $65 \%$ coniferous and $55 \%$ non-coniferous) and residues (35\% coniferous and $45 \%$ non-coniferous) (Table 3 ).

Table 3. Distribution of sawmills production and residues in the production of individual wood products.

\begin{tabular}{ccccccc}
\hline $\begin{array}{c}\text { Conversion Factors/ } \\
\text { Residues Distribution }\end{array}$ & \multicolumn{2}{c}{ I.-III. Quality Grades } & \multicolumn{2}{c}{ IV. and V. Quality Grades } & \multirow{2}{*}{ Remark } \\
\hline & Timber (C) & Timber (NC) & Timber (C) & Timber (NC) & \\
\hline & & \multicolumn{2}{c}{$\%$} \\
\hline Sawnwood (C) & 65 & - & 65 & - & \\
Sawnwood (NC) & - & 55 & - & - & Distribution of \\
Wood-based panels & 35 & 20 & 17.5 & - & residues from \\
Paper & - & - & 17.5 & - & sawnwood \\
Other & - & 25 & 100 & - & production \\
\hline Total & 100 & 100 & &
\end{tabular}

Based on the relative distribution of products shown in Table 3, volume of residues from sawnwood production were used as feedstock for the production of wood-based panels and for energy production using the following proportions:

- $\quad$ wood-based panels production (all residues from the production of coniferous sawn manufactured from saw logs, $50 \%$ of residues from the production of coniferous sawnwood manufactured from coniferous pulpwood and $44 \%$ of residues from the production of non-coniferous sawnwood manufactured from non-coniferous logs);

- energy production (50\% of residues from the production of coniferous sawnwood manufactured from coniferous pulpwood and $56 \%$ of residues from the production of non-coniferous sawnwood manufactured from non-coniferous logs). 


\subsection{Calculation of Carbon Emissions and Removals from HWP}

In order to account for carbon in the HWP pool we followed the 2013 Revised Supplementary Methods and Good Practice Guidance Arising from the Kyoto Protocol [43]. For scenario S0 we applied the Tier 2 method with the default first order decay (FOD) function (see e.g., [44]). To estimate the carbon stock and the annual changes for each of the HWP categories: sawnwood (coniferous/non-coniferous), wood-based panels, paper and paperboard we used the following FOD function with default half-lives of 35,25 , and 2 years, respectively (IPCC [43], Equation 2.8.5):

$$
\begin{gathered}
C_{i+1}=e^{-k} \times C_{i}+\left[\frac{1-e^{-k}}{k}\right] \times \text { Inflow }_{i} \\
\Delta C_{i}=C_{i+1}-C_{i}
\end{gathered}
$$

where:

$i$-index for year

$C_{i}$ - the carbon stock in the particular HWP category at the beginning of year i, Gg C

$k$-decay constant of FOD for each HWP category (HWPj) given in units year- $1(k=\ln (2) / H L$, where HL is the half-life of the HWP pool in years

Inflow $w_{i}$ - the inflow to the particular HWP category (HWPj) during year i, Gg C yr-1

$\Delta C_{i}$-carbon stock change of the HWP category during year i, Gg $C$ year ${ }^{-1}$

The initial carbon stock in the HWP pool at $\mathrm{t}=\mathrm{t}_{0}$ was estimated using the Equation (2) (IPCC [43], Equation 2.8.6):

$$
\begin{gathered}
C\left(t_{0}\right)=\frac{\text { Inflow }_{\text {average }}}{k} \\
\text { Inflow } \text { average }=\sum_{i=t_{0}}^{t=4} \text { Inflow }_{i} / 5
\end{gathered}
$$

The estimates of the HWP carbon pool starts with $i=1990$ and C(1990) $=0$.

For the conversion of wood volume or weight (in case of paper and paperboard) into carbon the default conversion factors and half-lives stipulated by IPCC shown in Table 4 were used.

Table 4. Carbon conversion factors and half-lives used in modelling.

\begin{tabular}{lll}
\hline \multirow{2}{*}{ HWP Categories } & C Conversion Factor & Half-Life \\
\cline { 2 - 3 } & {$\left[{\left.\mathrm{Mg} \mathrm{C} . \mathrm{m}^{-3}\right]}^{\text {[years] }}\right.$} \\
\hline Sawnwood & 0.229 & 35 \\
Coniferous sawnwood & 0.225 & 35 \\
Non-coniferous sawnwood & 0.280 & 35 \\
Wood-based panels & 0.269 & 25 \\
\hline & {$\left[\mathrm{Mg} \mathrm{C}^{\left.-\mathrm{Mg}^{-1}\right]}\right.$} & \\
\hline Paper and paperboard & 0.386 & 2 \\
\hline
\end{tabular}

By multiplying by $-44 / 12$ the carbon stock change is converted into $\mathrm{Gg} \mathrm{CO}_{2}$ year-1. Resulting values of annual carbon stock changes and the HWP emissions and removals of $\mathrm{CO}_{2}$ from pool were calculated individually for each of the scenarios. This allowed us to evaluate the impact of different use of available wood potential on HWP carbon balance over the forecasted period. 


\subsection{Projection of Timber Felling}

The conditions for forecasting the future development of timber felling are currently very complicated, mainly because of the development of accidental timber felling due to harmful factors (dominated by bark beetle), especially in coniferous forests dominated by spruce. To determine the timber felling development till 2035, the data of summary forest management plans and the results of permanent forest inventory since 1985 were used. Using the ratio of actual and planned felling during the last 20 years, the volume of expected actual felling was determined and allocated to age classes based on the calculated intensity of extracting wood stock in age classes. The increment was calculated using the growth tables data and the volume of growing stock was moved one age class up (increasing the age by 10 years). This was used for determining the expected felling plan for the next decade. These steps were repeated for the whole forecasted period (up to 2035).

\section{Results}

Timber felling forecast is shown in Table 5. The volume of total felling by 2035 should range from 8.8 mil. $\mathrm{m}^{3}$ to $9.0 \mathrm{mil} . \mathrm{m}^{3}$, peaking around 2030. The volume of regeneration felling is expected to increase while tending felling should slow down. Non-coniferous felling will have an increasing tendency. By contrast, coniferous felling (mainly spruce) will be reduced due to its high level of accidental felling. The resulting rate of reduction of timber felling after 2030, the time of actual start of its reduction, as well as the future age composition of forests, will be influenced especially by the extent of future accidental felling and the way of regulation of timber felling in times of increased logging possibilities.

Table 5. Timber felling forecast until 2035.

\begin{tabular}{lccccc}
\hline \multirow{2}{*}{$\begin{array}{c}\text { Projected } \\
\text { Timber Felling }\end{array}$} & $\mathbf{2 0 1 5}$ & $\mathbf{2 0 2 0}$ & $\mathbf{2 0 2 5}$ & $\mathbf{2 0 3 0}$ & $\mathbf{2 0 3 5}$ \\
\cline { 2 - 6 } & \multicolumn{5}{c}{$\mathbf{1 0 0 0} \mathbf{~ m}^{\mathbf{3}}$ Under Bark } \\
\hline Total & 8833.7 & 8898.1 & 8957.9 & 9001.1 & 8988.9 \\
Regeneration & 7377.3 & 7545.3 & 7649.3 & 7733.0 & 7744.1 \\
Tending & 1456.4 & 1352.8 & 1308.6 & 1268.1 & 1244.8 \\
Coniferous & 4640.9 & 4501.5 & 4367.5 & 4249.6 & 4109.0 \\
Non-coniferous & 4192.8 & 4396.6 & 4590.4 & 4751.5 & 4879.9 \\
\hline
\end{tabular}

Individual scenarios were defined considering different assumptions regarding the utilization potential and wood production structure and the level of industrial roundwood foreign trade. Based on this underlying information, the development of each scenario is described in terms of trends in the structure and volume of produced timber assortments and final wood products, and the changes in carbon stocks and HWP emissions and removals of $\mathrm{CO}_{2}$ for the projection period are quantified.

\subsection{Scenario SO-Basic Scenario}

This scenario is based on the real structure of domestically supplied wood and real level of industrial roundwood foreign trade. The quantified values resulting from this scenario serve as reference frameworks for comparison with the results of other scenarios. Within this, the wood production is dominated by non-coniferous timber, namely non-coniferous pulpwood and non-coniferous sawlogs. In the forecasted period, the production of non-coniferous pulpwood will increase from $2.5 \mathrm{mil} . \mathrm{m}^{3}$ to over 3 mil. $\mathrm{m}^{3}$ and non-coniferous sawlogs from $1.3 \mathrm{mil} . \mathrm{m}^{3}$ to $1.65 \mathrm{mil} . \mathrm{m}^{3}$. In contrast, the production of coniferous sawlogs will decrease by 0.38 million $\mathrm{m}^{3}$ and coniferous pulpwood by 0.5 million $\mathrm{m}^{3}$ after 2020 (Table 6). 
Table 6. Forecast of timber quality grades production until 2035.

\begin{tabular}{|c|c|c|c|c|c|c|c|c|}
\hline \multirow[t]{3}{*}{ Scenario } & \multirow[t]{3}{*}{ Year } & \multicolumn{3}{|c|}{ Coniferous } & \multicolumn{3}{|c|}{ Non-Coniferous } & \multirow[t]{2}{*}{ Total } \\
\hline & & Sawlogs & Pulpwo & Fuelwoc & Sawlogs & Pulpwo & Fuelwood & \\
\hline & & \multicolumn{7}{|c|}{$1000 \mathrm{~m}^{3}$} \\
\hline \multirow{2}{*}{ S0 } & 2017 & 2313.7 & 1343.5 & 226.7 & 1302.9 & 2546.7 & 358.1 & 8091.4 \\
\hline & 2035 & 1676.7 & 732.8 & 227.2 & 1654.1 & 3013.9 & 466.4 & 7771.2 \\
\hline \multirow{2}{*}{ S1 } & 2017 & 3427.6 & 1783.8 & 277.0 & 1473.9 & 2166.4 & 266.3 & 9394.9 \\
\hline & 2035 & 2657.7 & 1185.0 & 266.3 & 1814.3 & 2698.1 & 367.5 & 8988.9 \\
\hline \multirow{2}{*}{ S2 } & 2017 & 3129.1 & 719.2 & 47.5 & 1853.3 & 2024.4 & 82.8 & 7856.3 \\
\hline & 2035 & 2188.7 & 414.0 & 34.1 & 2366.1 & 2367.8 & 208.8 & 7579.5 \\
\hline \multirow{2}{*}{ S3 } & 2017 & 4465.9 & 1220.4 & 103.1 & 1974.2 & 1603.6 & 235.7 & 9602.9 \\
\hline & 2035 & 3169.7 & 866.2 & 73.1 & 2526.3 & 2052.0 & 301.6 & 8988.9 \\
\hline
\end{tabular}

This trend will be reflected in the structure of HWP production, where wood-based panels will dominate. However, their production will decrease from around $1.2 \mathrm{mil}^{\mathrm{m}} \mathrm{m}^{3}$ to $0.75 \mathrm{mil} . \mathrm{m}^{3}$ in 2035 (total decrease by $37 \%$ ). A similar trend can be seen in the production of coniferous sawnwood, volume of which will decrease from 0.94 mil. $\mathrm{m}^{3}$ to $0.52 \mathrm{mil}^{3} \mathrm{~m}^{3}$ by 2035 (by $45 \%$ ). Subsequently, the production of non-coniferous sawnwood is expected to increase by $32.5 \%$ and paper and paperboard production by $22 \%$ (Table 7 ).

Table 7. Production of harvested wood products forecast until 2035.

\begin{tabular}{|c|c|c|c|c|c|}
\hline \multirow[t]{2}{*}{ Scenario } & \multirow[t]{2}{*}{ Year } & $\begin{array}{l}\text { Coniferous } \\
\text { Sawnwood }\end{array}$ & $\begin{array}{l}\text { Non-Coniferous } \\
\text { Sawnwood }\end{array}$ & $\begin{array}{l}\text { Wood Based } \\
\text { Panels }\end{array}$ & \multirow{2}{*}{$\begin{array}{c}\text { Paper and } \\
\text { Paperboard } \\
1000 \text { tons }\end{array}$} \\
\hline & & & $1000 \mathrm{~m}^{3}$ & & \\
\hline \multirow{2}{*}{ So } & 2017 & 944.6 & 320.7 & 1199.6 & 561.3 \\
\hline & 2035 & 520.6 & 425.0 & 750.0 & 683.5 \\
\hline \multirow{2}{*}{$\mathrm{S} 1$} & 2017 & 1365.6 & 430.0 & 1238.1 & 745.2 \\
\hline & 2035 & 974.0 & 545.9 & 846.9 & 891.3 \\
\hline \multirow{2}{*}{ S2 } & 2017 & 1636.3 & 604.2 & 1345.9 & 420.4 \\
\hline & 2035 & 982.7 & 790.1 & 926.8 & 515.5 \\
\hline \multirow[b]{2}{*}{ S3 } & 2017 & 2942.5 & 760.1 & 2029.4 & 520.9 \\
\hline & 2035 & 2088.4 & 972.6 & 1558.5 & 666.5 \\
\hline
\end{tabular}

The projected values of production are finally converted into the volumes of carbon sequestration in the different HWP. It follows from scenario S0 that roughly 3.7 mil. tons $\mathrm{CO}_{2}$ was sequestered in HWP. Simultaneously, 2.2 mil. tons were emitted to the atmosphere from consumption of HWP in 2017. Wood-based panels stored 1.21 mil. tons $\mathrm{CO}_{2}$ with the balance more than 0,77 mil. tons $\mathrm{CO}_{2}$. The overall HWP balance is positive as the volume of $\mathrm{CO}_{2}$ stored in HWP has increased by $1.5 \mathrm{mil}$. tons in 2017 (Table 8). Due to the changes in wood assortments by 2035, we expect that the amount of $\mathrm{CO}_{2}$ stored in HWP will be reduced to 0.547 mil. tons. At the same time, wood-based panels will still store the highest $\mathrm{CO}_{2}$ volume among $\mathrm{HWP}(0.84 \mathrm{mil}$. tons) with a positive balance $(0.74 \mathrm{mil}$. tons). Overall, the amount of $\mathrm{CO}_{2}$ stored in HWP will decrease by 0.99 mil. tons compared to 2017 (Table 8). 
Table 8. Current and forecasted $\mathrm{CO}_{2}$ balance by 2035 .

\begin{tabular}{|c|c|c|c|c|c|c|c|}
\hline Scenario & Year & $\begin{array}{c}\mathrm{CO}_{2} \\
\text { Balance }\end{array}$ & Total & $\begin{array}{l}\text { Coniferous } \\
\text { Sawnwood }\end{array}$ & $\begin{array}{l}\text { Non-Coniferous } \\
\text { Sawnwood }\end{array}$ & $\begin{array}{l}\text { Wood Based } \\
\text { Panels }\end{array}$ & $\begin{array}{l}\text { Paper and } \\
\text { Paperboard }\end{array}$ \\
\hline & & & & & 1000 tons & & \\
\hline \multirow{6}{*}{ S0 } & \multirow{3}{*}{2017} & Removals & -3743.76 & -1072.40 & -437.08 & -1209.05 & -1025.23 \\
\hline & & Emissions & 2208.51 & 550.93 & 328.16 & 434.96 & 894.46 \\
\hline & & Difference & -1535.25 & -521.47 & -108.92 & -774.09 & -130.77 \\
\hline & \multirow{3}{*}{2035} & Removals & -3460.25 & -803.52 & -560.35 & -835.23 & -1261.15 \\
\hline & & Emissions & 2912.84 & 657.04 & 386.50 & 627.51 & 1241.79 \\
\hline & & Difference & -547.41 & -146.48 & -173.85 & -207.71 & -19.36 \\
\hline \multirow{6}{*}{ S1 } & \multirow{3}{*}{2017} & Removals & -4709.83 & -1617.56 & -498.27 & -1681.41 & -912.58 \\
\hline & & Emissions & 2194.80 & 567.51 & 329.89 & 454.29 & 843.10 \\
\hline & & Difference & -2515.03 & -1050.05 & -168.38 & -1227.12 & -69.48 \\
\hline & \multirow{3}{*}{2035} & Removals & -4328.91 & -1274.96 & -614.70 & -1270.58 & -1168.67 \\
\hline & & Emissions & 3174.59 & 810.53 & 404.06 & 810.62 & 1149.38 \\
\hline & & Difference & -1154.32 & -464.43 & -210.64 & -459.96 & -19.29 \\
\hline \multirow{6}{*}{ S2 } & \multirow{3}{*}{2017} & Removals & -4599.02 & -1688.80 & -715.01 & -1354.52 & -840.69 \\
\hline & & Emissions & 2153.54 & 566.80 & 337.23 & 441.00 & 808.51 \\
\hline & & Difference & -2445.48 & -1122.00 & -377.78 & -913.52 & -32.18 \\
\hline & \multirow{3}{*}{2035} & Removals & -4152.95 & -1184.72 & -935.13 & -1009.65 & -1023.45 \\
\hline & & Emissions & 2999.80 & 795.56 & 497.38 & 698.87 & 1007.99 \\
\hline & & Difference & -1153.15 & -389.16 & -437.75 & -310.78 & -15.46 \\
\hline \multirow{6}{*}{ S3 } & \multirow{3}{*}{2017} & Removals & -5762.38 & -2313.91 & -786.43 & -1919.09 & -742.95 \\
\hline & & Emissions & 2152.83 & 585.85 & 339.26 & 463.94 & 763.78 \\
\hline & & Difference & -3609.55 & -1728.06 & -447.17 & -1455.15 & 20.83 \\
\hline & \multirow{3}{*}{2035} & Removals & -5202.08 & -1722.97 & -998.57 & -1537.19 & -943.36 \\
\hline & & Emissions & 3337.12 & 970.90 & 517.87 & 920.39 & 927.95 \\
\hline & & Difference & -1864.96 & -752.07 & -480.70 & -616.80 & -15.41 \\
\hline
\end{tabular}

\subsection{S1-Real Scenario Excluding Foreign Trade}

The next theoretical scenario S1 excluded the foreign trade and assumed the use of the real timber assortment structure. In this scenario the domestic wood supplies of coniferous sawlogs will be $52 \%$ higher on average compared to the reference scenario $\mathrm{S} 0$, although the production of coniferous sawlogs will gradually decrease (by $22 \%$ by 2035). The second largest volume is represented by the supplies of non-coniferous pulpwood. Their volume is lower by $12 \%$ compared to scenario S0; however, they show an upward trend with an increase of 0.5 mil. $\mathrm{m}^{3}$ by 2035. A similar trend can be observed in the case of non-coniferous sawlogs with an increase of 0.34 mil. $\mathrm{m}^{3}$ (Table 6). In this scenario, coniferous sawnwood is the most important HWP; however, its production will decrease from 1.36 mil. $\mathrm{m}^{3}$ to 0.97 mil. $\mathrm{m}^{3}$ in 2035. A similar trend is projected in the production of wood-based panels (decrease by $32 \%)$. On the other side, non-coniferous sawnwood, paper and paperboard production will have an increasing trend (more than $20 \%$ ) (Table 7).

In 2017, $\mathrm{CO}_{2}$ stored in HWP increased to 4.7 mil. tons, $\mathrm{CO}_{2}$ released into the atmosphere was approximately 2.2 mil. tons and the $\mathrm{CO}_{2}$ balance reached 2.5 mil. tons in 2017. As in the case of reference scenario, wood-based panels still stored the highest volume of $\mathrm{CO}_{2}(1.68 \mathrm{mil}$. tons) with the carbon balance almost 1.23 mil. tons, followed by non-coniferous sawnwood, which stored 1.62 mil. tons $\mathrm{CO}_{2}$ with the carbon balance 1.05 mil. tons (Table 8). In 2035, it is projected that this situation will change, with the highest volume of $\mathrm{CO}_{2}$ being stored by non-coniferous sawnwood (1.28 mil. tons). Over the analyzed period, the $\mathrm{CO}_{2}$ stored in HWP will be gradually decreased to about 4.33 mil. tons and $\mathrm{CO}_{2}$ released into the atmosphere will markedly increase to 3.18 mil. tons. Owing to the above-mentioned changes in the structure of $\mathrm{HWP}$, the $\mathrm{CO}_{2}$ balance will decrease to $1.15 \mathrm{mil}$. tons. Compared to the reference scenario $\mathrm{S} 0$, the $\mathrm{CO}_{2}$ balance of $\mathrm{HWP}$ was higher by 0.98 mil. tons $(64 \%)$ in 2017 and will increase by 0.61 mil. tons $(111 \%)$ by 2035 (Table 8 ). 


\subsection{S2-Ideal Scenario}

Scenario S2 represents the combination of the modelled structure of assortments and the actual level of foreign trade. It assumes a relatively balanced consumption of sawlogs and non-coniferous pulpwood in the forecasted period between 2020 and 2035. As in the previous scenarios S0 and S1, a downward trend in the supply of coniferous wood and an increase in non-coniferous sawlogs and pulpwood supplies can be observed. S2 scenario also assumes higher domestic consumption of more valuable assortments of coniferous (by $32 \%$ ) and non-coniferous (by $43 \%$ ) sawlogs. In contrast, it predicts lower supplies of coniferous (by 44\%) and non-coniferous (by 21\%) pulpwood till 2035 (Table 6). According to this scenario, the ideal utilization of coniferous roundwood is reflected in the increased production of coniferous sawnwood and wood-based panels. Nevertheless, their production will experience a downward trend, while the production of other products (non-coniferous sawnwood, wood-based panels, and paper) will show a rising trend (Table 7).

Timber supply changes will affect the HWP carbon sequestration. For the S2 scenario, HWP stored over 2.4 mil. tons of $\mathrm{CO}_{2}$ in 2017, but due to changes in wood supply and structure of the HWP, the overall carbon balance will gradually decrease by 1.29 mil. tons (53\%) of $\mathrm{CO}_{2}$ by 2035 . Coniferous sawnwood stores the highest volume of $\mathrm{CO}_{2}$ amounts with 1.69 mil. tons in 2017 and 1.19 mil tons in 2035 (Table 8).

\subsection{S3-Ideal Scenario Excluding Foreign Trade}

Scenario 33 combines the advantages of the two previous scenarios by considering the optimization of the quality of the harvested timber (scenario S2) and increasing domestic consumption resulting from the elimination of foreign trade with industrial roundwood (scenario S1). This is the most appropriate theoretical variant, considering the economic, environmental, and social benefits of efficient production. In the forecasted period, the timber supplies will be dominated by coniferous sawlogs (more by $84 \%$ compared to the scenario S0), non-coniferous sawlogs (more by 54\%), and non-coniferous pulpwood ( $32 \%$ less than the scenario S0). At the same time, the supply of coniferous timber will have a downward trend. In particular, the supplies of sawlogs will decrease by $29 \%$ till 2035 . On the other side, the supply of non-coniferous sawlogs and pulpwood will increase (both by $28 \%$ ) (Table 6).

In 2017, the production of coniferous sawnwood was 3.79 mil. $\mathrm{m}^{3}$ (3.5 times higher compared to the scenario S0), non-coniferous sawnwood was $2.1 \mathrm{mil} . \mathrm{m}^{3}$ (2.3 times higher), and the production of paper and paperboard production was approximately $3 \%$ lower compared to scenario S0. As in the previous scenarios S1 and S2, the production of coniferous HWP will have a downward trend. In particular, by 2035 the production of coniferous sawnwood (1.64 mil. $\mathrm{m}^{3}$ in 2017) will decrease by $29 \%$ and production of wood-based panels $\left(1.35 \mathrm{mil} . \mathrm{m}^{3}\right.$ in 2017$)$ by $23 \%$, respectively. On the other hand, the production of non-coniferous sawnwood, paper, and paperboards will increase by $28 \%$ (Table 7).

Within scenario S3, the total balance of $\mathrm{CO}_{2}$ stored in HWP was 3.6 mil. tons in 2017. The production of coniferous sawnwood stored an even higher volume of $\mathrm{CO}_{2}$ (2.31 mil. tons in 2017 and $1.73 \mathrm{mil}$ tons in 2035) compared to the previous scenario S2 (Table 8). When analyzing the development in the forecasted period, there is a significant difference in the balance of $\mathrm{CO}_{2}$ stored in coniferous sawnwood between 2017 and 2035, which dropped by $57 \%$ from 1.73 mil. tons to 0.75 mil. tons. By 2035, the total balance of $\mathrm{CO}_{2}$ stored in HWP will gradually decrease to the volume around 1.87 mil. tons. Nevertheless, the scenario S3 assumes that the total balance of $\mathrm{CO}_{2}$ stored in $\mathrm{HWP}$ was 2.3 times higher ( 2.07 mil. tons) in 2017 and will be 3.4 times higher (1.32 mil. tons) in 2035 compared to the volumes in the reference scenario $\mathrm{S} 0$ (Table 8 ).

\section{Discussion}

Under the auspices of the United Nations Framework Convention on Climate Change, the world's leading forums in the fight against climate change and global warming promote the production of timber and wood products produced in a sustainable and environmentally friendly way. They 
protect the Earth's atmosphere by sequestering carbon in forests, binding it in HWP, and replacing non-renewable raw materials that are produced with a larger carbon footprint. Ensuring sustainable forest management and continuing environmentally positive innovations in the sectors of wood processing and utilization are crucial to meeting these objectives.

This study aims to project a future development of volumes and structure of wood supplies and their utilization in Slovakia, based on the defined modelled situations and to estimate the contribution of produced HWP to mitigate climate changes in terms of their potential to store carbon.

The proposed scenarios try to respond to the current problems of the forestry and forest-based sector in Slovakia, which mainly include high exports of roundwood in connection with the insufficient domestic consumption and low value added in wood value chains [33,34]. Therefore, these scenarios focus on better utilization of available wood resources in terms of improving the structure of quality grades of wood supplies as well as the prospect of a domestic market to increase timber consumption from domestic sources. The improved patterns of wood utilization are reflected in the changes in structure of HWP production, as well as the availability of HWP to sequester carbon.

All projections were based on the forecasted volumes of felling by 2035, determined on the comprehensive historic data available from domestic inventory, methods of continuous surveys, and evaluation of forest resources. Allowable cut is primarily based on the level of standing volume and harvesting capability. In 2018, standing volume was 481.8 mil. $\mathrm{m}^{3}$ under bark [31] and is currently peaking. It is expected that in the coming years and decades the total timber stock will decrease as a result of a gradual change in the age structure of forests. However, at this stage of climate change, an increase in temperatures, carbon dioxide in the atmosphere, and an increase in the amount of nitrogen in the soil may also have some impact on the observed development of standing volumes. The acceleration of forest growth in Central and Northern Europe in the second half of the 20th century was documented, e.g., by Spiecker et al. [45] and Pretzsch et al. [46]. The current factors, like climate change, intensity and volumes of accidental felling, as well as political and socio-economic factors, have a significant impact on the structure of future wood resources and tree distribution. Forecasted changes will also be reflected in the volumes and structure of future felling. The current above-allowable felling level in coniferous stands, caused by the accidental felling (spruce and pine), and below-allowable felling in broadleaves stands, in particular due to postponing regeneration of beech and oak, will result in decreasing volumes of felled coniferous timber and higher felled volumes of non-coniferous timber [47,48].

The forecasted production of HWP is determined on the basis of development of available wood resources divided into individual quality grades following the patterns of actual wood processing in Slovakia [33]. Projected changes in timber supply structure will have a significant effect on future wood material flows and the structure of HWP markets. At the present time, the sawmilling industry can be considered as one of the most important domestic wood processing sectors. In Slovakia, sawmills are mainly focused on the production of coniferous sawnwood, dominated by spruce sawnwood for construction purposes [49]. Besides several large sawmills, there is a large number of small- and medium-sized businesses with outdated technologies, insufficient financial resources, investments, and innovations [50]. Based on the results of this study, this sector will be the most negatively affected by the changes in tree species composition and felling structure, as it will face a shortage of available raw material. In contrast, the production of pulp and paper, which is mainly focused on the consumption of domestic non-coniferous pulpwood and is characterized by more homogeneous structure in terms of production [51] is expected to be positively influenced by the changes in the structure of forests. Furthermore, a growing trend of harvested volumes is expected to be stopped and the total amount of carbon stored in the HWP in Slovakia will decrease by $0.28 \mathrm{Gg}$ in 2035.

The study was aimed at the estimation of the influence of changes in utilization of available wood resources on the level of carbon balance in HWP. It was based on the comparison of results of the basic scenario, represented by the reference scenario $\mathrm{S}$, with other alternative scenarios represented by the scenarios S1, S2, and S3. Scenario S0 represents the real structure of domestically supplied wood 
assortments and actual situation on the wood market with a starting level of $1.54 \mathrm{Gg}$ carbon balance in 2017 and final carbon balance $0.55 \mathrm{Gg}$ in 2035. This minimalistic scenario reflects the current and forecasted situation without any improvement in wood utilization. Additional scenarios S1 and S2 represent the state where either the wood quality structure has improved or the wood resources are utilized for domestic consumption. The proportion of longer half-life products would have increased, if the forest industry would be able to efficiently utilize wood resources respecting the growth potential of forests and changes in tree distribution in Slovakia. According to scenario S1, in 2017 the carbon balance was estimated at the level $2.51 \mathrm{Gg}$ and decreased to $1.15 \mathrm{Gg}$ in 2035. The scenario S1 represents the situation where the domestic wood consumption would increase due to the exclusion of industrial roundwood export. A higher consumption of domestic wood would arise from the development in the capacity and structure of the wood processing industry encouraged by the expansion of the existing production potential and implementation of innovation related mainly to value added products. The additional production of HWP would increase the carbon stock to $4.71 \mathrm{Gg}$ in 2017 and $4.33 \mathrm{Gg}$ in 2035. However, it has to be acknowledged that the exclusion of exports has no effect on the carbon balance from a global perspective as it can be assumed that exported timber will be used for the production of HWP abroad in a similar way. Therefore, scenario S1 emphasizes the importance of domestic wood resources in terms of carbon balance in Slovakia and can be used for demonstrating the economic, environmental, and social benefits. These benefits consist mainly of generating added value, sequestering carbon in domestic wood products, creating jobs, and investing in expanding the processing capacity with regard to the volume and structure of wood resources available.

Under scenario S2, carbon sinks of $2.45 \mathrm{Gg}$ and $1.15 \mathrm{Gg}$ were estimated in 2017 and in 2035, respectively. This scenario resulted from changes in wood volumes, in particular shifts to the higher grades of quality, which are principally used for sawnwood or solid wood product production, consequently utilized in the construction sector and furniture industry. At the same, there is a lower share of fuelwood production assumed due to the utilization of this feedstock for industrial purpose (primarily pulpwood). This has a positive effect on the carbon stock level as the paper produced from pulpwood has a longer lifetime and can be easily recycled compared to fuelwood. Similar results were described by Brunet-Navarro [52], who confirmed that the two most important factors having impact on the carbon stock in HWP are longevity and recycling rate. This scenario is also considered to be an ideal scenario. It is developed on the basis of additional data calculated and considered in defining the improved utilization of available wood resources and talking into account the changed wood material flows. Some authors [28,53] described that the value of carbon stock can vary with the different methodology used or input data. Obviously, more detailed input data yield more accurate results of carbon stock level estimations. This is also reflected by [20], who, aiming to improve the final values of annual changes in carbon stocks in HWP, described how to use direct stock inventories of wood products for calculation. Also, Donlan [23] agreed with this idea and claimed that all countries are advised to include detailed data about material flows as much as possible.

Scenario S3 demonstrates the highest level of carbon stock. It fully reflects the cumulative positive impacts of improving utilization of wood assortments and an increase in domestic consumption by eliminating wood export. Since neither of these conditions can be immediately applied in practice, this scenario can be considered as a target, which could be applied in the forestry and forest-based sector after the implementation of appropriate measures, e.g., forest policy support, green building initiatives promotion, investments into innovative technologies for the production of longer lifetime products, and new applications of wood in other sectors.

The presented results confirm that the future changes in wood assortment structure will have a significant influence on the carbon pool in HWP. Though, for Slovakia, the expected development will not have a positive effect on carbon balance in HWP. The production of coniferous sawlogs, which is principally used in the construction industry to produce long-life products will decrease. This is negatively reflected in the ability of HWP to store carbon. On the other side, we assume the higher production of lower quality non-coniferous wood assortments (pulpwood) mainly utilized for the pulp 
and paper production; the products which a generally shorter lifetime. These are the main reasons why all four scenarios point to a significant fall in carbon-binding capacity of HWP in the future. However, as indicated, any improvements in the efficiency of utilization of available wood resources can eliminate the impact of these negative tendencies. Additionally, the trends in the structure of wood supplies in Slovakia indicate changes that are crucial for the whole wood processing industry and the companies will face these challenges and have to find ways how to adapt to these changes.

\section{Conclusions}

Sustainably managed forests provide renewable raw wood material, important environmental and social values, services, employment in often vulnerable rural areas, and they play a vital role in the carbon cycle. Forestry and forest-based industries play a key role in the transition to a sustainable green economy. The green economy, which is defined as low carbon, resource efficient and socially inclusive, offers solutions to the economic, ecological, and social problems resulting from rapidly growing human populations, overexploitation of natural resources, environmental pollution, and a number of other factors causing the disruption of natural balance, in particular climate change. The role of forests and forest products in this concept is inevitable. In this context, this study highlights the social, economic, and environmental importance of wood production in a sustainable way (provision of optimal ecosystem services, including wood production) from the viewpoint of carbon sequestration. Therefore, the objective of this study was to point out the benefits resulting from the efficient utilization of wood resources and to determine the potential and contribution of HWP to climate change mitigation.

Based on the findings of this study, the following conclusions can be drawn:

- according to the results of the two different methods of inventory of standing volume and analysis of timber supplies, there are significant differences in the structure and utilization of the available domestic wood resources in terms of their quality,

- development of timber supplies after 2020 in Slovakia will be influenced, in particular, by the future changes in the age distribution and tree species composition as well as the extent of future accidental felling. Non-coniferous felling will have an increasing tendency, and, by contrast, coniferous felling (mainly spruce) will be reduced,

- by comparing the results of the four designed scenarios, it follows that the scenario with the greatest mitigation potential, is the one assuming the optimal use of wood assortments and limitation of industrial roundwood foreign trade,

- optimal utilization of available structure of wood assortments may result in the increase of production of long-life HWP and thus increase the HWP carbon pool,

- predicted structure and availability of wood resources in Slovakia will be reflected in a higher share of the production of products with shorter life cycle and thus, will negatively influence the carbon pool in HWP,

- future changes in the composition of forests in an effort to adapt the climate change may result in a reduction of the carbon-binding capacity in HWP and thus negatively affect the overall carbon balance.

Author Contributions: H.P. and M.D. prepared the literature review; J.P., H.P., M.M., M.K., and V.M. elaborated the chapters Material and Methods, and Results; H.P., J.P., M.D., M.M., and M.K. prepared the Discussion section; the conclusion section was written by H.P. and J.P. All authors have read and agreed to the published version of the manuscript.

Funding: The Scientific Grant Agency of the Ministry of Education, Science, Research and Sport of the Slovak Republic, and the Slovak Academy of Sciences, VEGA Grant No. 1/0666/19 "Determination of the development of a wood-based bioeconomy" and the Slovak Research and Development Agency, APVV-14-0869 "Research of the utilization of wood as a renewable raw material in the context of a green economy".

Acknowledgments: The authors are grateful for the support of the Scientific Grant Agency of the Ministry of Education, Science, Research and Sport of the Slovak Republic and the authors are grateful for the support of the Slovak Research and Development Agency. 
Conflicts of Interest: The authors declare no conflicts of interest.

\section{References}

1. Liu, L.; Huang, G.; Baetz, B.; Huang, C.Z.; Zhang, K. Integrated GHG emissions and emission relationships analysis through a disaggregated ecologically-extended input-output model; A case study for Saskatchewan, Canada. Renew. Sustain. Energy Rev. 2019, 106, 97-109. [CrossRef]

2. European Commission. A Clean Planet for All-A European Long-Term Strategic Vision for a Prosperous, Modern, Competitive and Climate Neutral Economy; European Commission: Brussels, Belgium, 2018.

3. IPCC. Climate Change 2014: Synthesis Report. Contribution of Working Groups I, II and III to the Fifth Assessment Report of the Intergovernmental Panel on Climate Change; Pachauri, R.K., Meyer, L., Eds.; IPCC: Geneva, Switzerland, 2014.

4. Machar, I.; Voženílek, V.; Kirchner, K.; Vlčková, V.; Buček, A. Biogeographic model of climate conditions for vegetation zones in Czechia. Geogr. CGS 2017, 122, 64-82. [CrossRef]

5. Jasinevičius, G.; Lindner, M.; Pingoud, K.; Tykkylainen, M. Review of models for carbon accounting in harvested wood products. Int. Wood Prod. J. 2015, 6, 198-212. [CrossRef]

6. Parobek, J.; Paluš, H.; Moravčík, M.; Kovalčík, M.; Dzian, M.; Murgaš, V.; Šimo-Svrček, S. Changes in carbon balance of harvested wood products resulting from different wood utilization scenarios. Forests 2019, 10, 590. [CrossRef]

7. Tonn, B.; Marland, G. Carbon sequestration in wood products: A method for attribution to multiple parties. Environ. Sci. Policy 2007, 10, 162-168. [CrossRef]

8. Lippke, B.; Wilson, J.; Meil, J.; Taylor, A. Characterizing the importance of carbon stored in wood products. Wood Fiber Sci. 2010, 42, 5-14.

9. Nabuurs, G.; Delacote, P.; Ellison, D.; Hanewinkel, M.; Lindner, M.; Nesbit, M.; Ollikainen, M.; Savaresi, A. A New Role for Forests and the Forest Sector in the EU Post-2020 Climate Targets. From Science to Policy 2. European Forest Institute; European Forest Institute: Joensuu, Finland, 2015; ISBN 9789525980219.

10. Pilli, R.; Fiorese, G.; Grassi, G. EU mitigation potential of harvested wood products. Carbon Balance Manag. 2015, 10, 6. [CrossRef]

11. Sokka, L.; Koponen, K.; Keränen, J.T. Cascading Use of Wood in Finland-With Comparison to Selected EU Countries; VTT Technical Research Centre of Finland Ltd.: Espoo, Finland, 2014.

12. Parobek, J.; Paluš, H. The concept of cascade use of wood in Slovakia. In The path forward for wood products: A global perspective. In The Path Forward for Wood Products: A Global Perspective-Proceedings of Scientific Papers; WoodEMA, i.a.: Baton Rouge, LA, USA, 2016; pp. 101-106.

13. Sathre, R.; Gustavsson, L. Energy and carbon balances of wood cascade chains. Resour. Conserv. Recycl. 2006, 47, 332-355. [CrossRef]

14. Gustavsson, L.; Madlener, R.; Hoen, H.F.; Jungmeier, G.; Karjalainen, T.; KlÖhn, S.; Mahapatra, K.; Pohjola, J.; Solberg, B.; Spelter, H. The Role of Wood Material for Greenhouse Gas Mitigation. Mitig. Adapt. Strat. Glob. Chang. 2006, 11, 1097-1127. [CrossRef]

15. Gustavsson, L.; Pingoud, K.; Sathre, R. Carbon Dioxide Balance of Wood Substitution: Comparing Concreteand Wood-Framed Buildings. Mitig. Adapt. Strat. Glob. Chang. 2006, 11, 667-691. [CrossRef]

16. Bergman, R.; Puettmann, M.; Taylor, A.; Skog, K.E. The Carbon Impacts of Wood Products. For. Prod. J. 2014, 64, 220-231. [CrossRef]

17. Sikkema, R.; Junginger, M.; McFarlane, P.; Faaij, A. The GHG contribution of the cascaded use of harvested wood products in comparison with the use of wood for energy-A case study on available forest resources in Canada. Environ. Sci. Policy 2013, 31, 96-108. [CrossRef]

18. Pingoud, K.; Pohjola, J.; Valsta, L. Assessing the integrated climatic impacts of forestry and wood products. Silva Fenn. 2010, 44, 155-175. [CrossRef]

19. UN FCCC. Report of the Conference of the Parties Serving as the Meeting of the Parties to the Kyoto Protocol on its Seventh Session, Held in Durban from 28 November to 11 December 2011; UN FCCC: Bonn, Germany, 2012.

20. Pingoud, K.; Skog, K.E.; Martino, D.L.; Tonosaki, M.; Xiaoquan, Z. Harvested Wood Products-IPCC Guidelines for National Greenhouse Gas Inventories. In IPCC Guidelines for National Greenhouse Gas Inventories; IGES: Hayama, Japan, 2006; pp. 1-33. 
21. Stockmann, K.D.; Anderson, N.M.; Skog, K.E.; Healey, S.P.; Loeffler, D.R.; Jones, G.; Morrison, J.F. Estimates of carbon stored in harvested wood products from the United States forest service northern region, 1906-2010. Carbon Balance Manag. 2012, 7, 1. [CrossRef]

22. Dias, A.C.; Arroja, L.; Capela, I. Carbon storage in harvested wood products: Implications of different methodological procedures and input data-a case study for Portugal. Eur. J. For. Res. 2012, 131, 109-117. [CrossRef]

23. Donlan, J.; Skog, K.; Byrne, K.A. Carbon storage in harvested wood products for Ireland 1961-2009. Biomass Bioenergy 2012, 46, 731-738. [CrossRef]

24. Ji, C.; Cao, W.; Chen, Y.; Yang, H. Carbon balance and contribution of harvested wood products in China based on the production approach of the intergovernmental panel on climate change. Int. J. Environ. Res. Public Health 2016, 13, 1132. [CrossRef]

25. Zhang, L.; Sun, Y.; Song, T.; Xu, J. Harvested Wood Products as a Carbon Sink in China, 1900-2016. Int. J. Environ. Res. Public Health 2019, 16, 445. [CrossRef]

26. Skog, K.E. Sequestration of carbon in harvested wood products for the United States. For. Prod. J. 2008, 58, 56-72.

27. Jasinevičius, G.; Lindner, M.; Cienciala, E.; Tykkyläinen, M. Carbon Accounting in Harvested Wood Products: Assessment Using Material Flow Analysis Resulting in Larger Pools Compared to the IPCC Default Method. J. Ind. Ecol. 2018, 22, 121-131. [CrossRef]

28. Aleinikovas, M.; Jasinevičius, G.; Škema, M.; Beniušiene, L.; Šilinskas, B.; Varnagiryte-Kabašinskiene, I. Assessing the effects of accounting methods for carbon storage in harvested wood products on the national carbon budget of Lithuania. Forests 2018, 9, 737. [CrossRef]

29. Raši, R.; Cienciala, E.; Priwitzer, T.; Palán, Š.; Pavlenda, P. Carbon balance in harvested wood products in Slovakia. For. J. 2015, 61, 101-106.

30. Moravčík, M.; Kovalčík, M.; Paluš, H.; Parobek, J. Modelling of wood utilization in the transition to a green aconomy. In Proceedings of the The International Forests Products Congress, Trabzon, Turkey, 26-29 September 2018; p. 9.

31. National Forest Centre. Report on the Forest Sector of the Slovak Republic 2018 - GREEN REPORT; Ministry of Agriculture of the Slovak Republic, National Forest Centre: Zvolen, Slovakia, 2019; ISBN 978-80-8093-286-2.

32. Moravčík, M.; Kovalčík, M.; Murgaš, V.; Paluš, H.; Parobek, J. Modelovanie využitia dreva v kontexte zelenej ekonomiky. In Ekonomická Životaschopnost Lesnicko-Dřevařského Sektoru V Novodobých Podmínkách; Mendelova univerzita v Brně: Křtiny, Czech Republic, 2019; pp. 127-138.

33. Ministry of Agriculture of the Slovak Republi. Národný Program Využitia Potenciálu Dreva Slovenskej Republiky; Ministry of Agriculture if the Slovak Republic: Bratislava, Slovakia, 2013.

34. Ministry of Agriculture of the Slovak Republic. Akčný Plán Národného Programu Využitia Potenciálu Dreva Slovenskej Republiky; Ministry of Agriculture of the Slovak Republic: Bratislava, Slovakia, 2014.

35. Salek, L.; Sivacioglu, A.; Topacoglu, O.; Zahradnik, D.; Jerabkova, L.; Machar, I. Crowns of Old Remnant Oak Standards. Fresenius Environ. Bullet 2017, 26, 4023-4032.

36. FAOSTAT. Food and Agriculture Organization of the United Nations, Statistics Division. Forestry Production and Trade. Available online: http://www.fao.org/faostat/en/\#data/FO (accessed on 4 April 2019).

37. Petráš, R.; Nociar, V. Nové sortimentačné tabul'ky hlavných listnatých drevín. Lesn. Časopis For. J. 1990, 36, 535-552.

38. Mecko, J.; Petráš, R.; Nociar, V. Konštrukcia nových stromových sortimentačných tabuliek pre smrekovec, hrab a brezu. Lesn. Časopis For. J. 1994, 39, 209-221.

39. Petráš, R.; Mecko, J.; Nociar, V. Modely kvality surového dreva stromov topol'ových klonov. Lesn. Časopis For. J. 2007, 53, 83-97.

40. Šebeň, V. National Forest Inventory and Monitoring SR 2015-2016. Information, Methods, Results; National Forest Centre: Zvolen, Slovakia, 2017; ISBN 978-80-8093-234-3.

41. SUTN. STN 480055 Qualitative Classification of Softwood Round Timber; Slovenský ústav technickej normalizácie: Bratislava, Slovakia, 2004.

42. SUTN. STN 480056 Qualitative Classification of Hardwood Round Timber; Slovenský ústav technickej normalizácie: Bratislava, Slovakia, 2004.

43. IPCC. 2013 Revised Supplementary Methods and Good Practice Guidance Arising from the Kyoto Protocol; IPCC: Geneva, Switzerland, 2014; ISBN 9789291691401. 
44. Pingoud, K.; Wagner, F. Methane emissions from landfills and carbon dynamics of harvested wood products: The first-order decay revisited. Mitig. Adapt. Strat. Glob. Chang. 2006, 11, 961-978. [CrossRef]

45. Heinrich, S.; Mielikäinen, K.; Köhl, M.; Skovsgaard, J.P. Growth Trends in European Forests—Studies from 12 Countries; EFI Research Report 5; Springer: Berlin/Heidelberg, Germany, 1996; ISBN 978-3-540-61460-9.

46. Pretzsch, H.; Biber, P.; Schütze, G.; Uhl, E.; Rötzer, T. Forest stand growth dynamics in Central Europe have accelerated since 1870. Nat. Commun. 2014, 5, 1-10. [CrossRef]

47. Ministry of Agriculture of the Slovak Republic. National Forest Centre Návrh Národného Programu Využitia Potenciálu Dreva Slovenskej Republiky; Uznesenie vlády SR č. 492 zo dňa 21. augusta 2013; Ministry of Agriculture of the Slovak Republic: Bratislava, Slovakia, 2013.

48. Dzian, M. Prognózoavnie Vývoja Dodávok Dreva pre Slovenský Drevospracujúci Priemysel; Technická univerzita vo Zvolene: Zvolen, Slovakia, 2018; ISBN 978-80-228-3102-4.

49. Parobek, J.; Paluš, H.; Kaputa, V.; Šupín, M. Analysis of wood flows in Slovakia. BioResources 2014, 9 , 6453-6462. [CrossRef]

50. Loučanová, E.; Olšiaková, M.; Šupín, M. Assessment of the innovation activity of the wood processing industry. In Proceedings of the Digitalisation and Circular Economy: Forestry and Forestry Based Industry Implications, Varna, Bulgaria, 11-13 September 2019; Chobanova, R., Ed.; Union of Scientists of Bulgaria: Varna, Bulgaria, 2019; pp. 207-212.

51. Paluš, H. Trh a Obchod s Drevom a Výrobkami z Dreva; Technická univerzita vo Zvolene: Zvolen, Slovakia, 2013; ISBN 978-80-228-2587-0.

52. Brunet-Navarro, P.; Jochheim, H.; Kroiher, F.; Muys, B. Effect of cascade use on the carbon balance of the German and European wood sectors. J. Clean. Prod. 2018, 170, 137-146. [CrossRef]

53. Mantau, U. Wood flow analysis: Quantification of resource potentials, cascades and carbon effects. Biomass Bioenergy 2015, 79, 28-38. [CrossRef]

(C) 2020 by the authors. Licensee MDPI, Basel, Switzerland. This article is an open access article distributed under the terms and conditions of the Creative Commons Attribution (CC BY) license (http://creativecommons.org/licenses/by/4.0/). 